$P E-060-01$
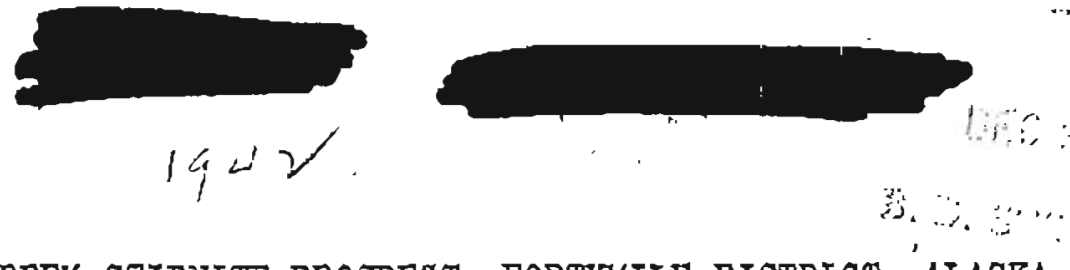

PRELIVINARY REPORT ON MY OREEK SIIBIITT PROSPECT, FORTYMILE DISTRICT, ALASEA $60-18$ ? $K \times 60.62$

\title{
Location
}

In July, 1942, an exemination was made by the writers of a stibnite prospect on My Creek, near the head of the MAdle Fork of the Fortymile I1ter. My Creek Is a wegt-flowlng tributerg of Holly Creek, which is the easternmost of two large streams that constitute the headwaters of the Middle Fork of the Fortymile River.

The stibnlte prospect is situated at an altitude of about 4,000 peet, in a broad sadils of the ridge south of My Creok. It is about fire miles east off the mouth of My Creek and 12 miles soutinest of Mt. Veta, (see U. S. Geol. Surveg Circle quadrangle map). At present the neere日t ugeable landing fleld ia at Chicken, about 50 afrline miles to the east, or about 70 miles on foot.

\section{Minting Clairas}

Two lode claims, meavuring approxtmately 600 by 1,500 feet each, have been staked by Dan Manske of Salmbanks and Fred Purdy of Chicken. According to the location notices the clatms are namod Grey Holf No. 1 and Grey Wolf No. 2; the owners are Anme and Fred Purdy, Lasetta and Dan Manake, and Ftbyl and Hilliam Taft.

\section{Showl neg}

In the vielnt ty of the prospect the country rook is mainly quarty mica schlst and quartzite schist, overlain br about five feet of noss, silt and alide rock. No exposures of rock in place were seen.

The stibnite occurs in a zone of white, vuggy quartz that 18 over 100 feet wide in places and $1 \mathrm{~g}$ traceable by meang of flokt for over 1,500 feet (see gicetch). In the unconsolidated material over the quartz zone the coarse float cong1ats almost ontirely of vein quartz. Some of these quartz masses are several foet aoross. 

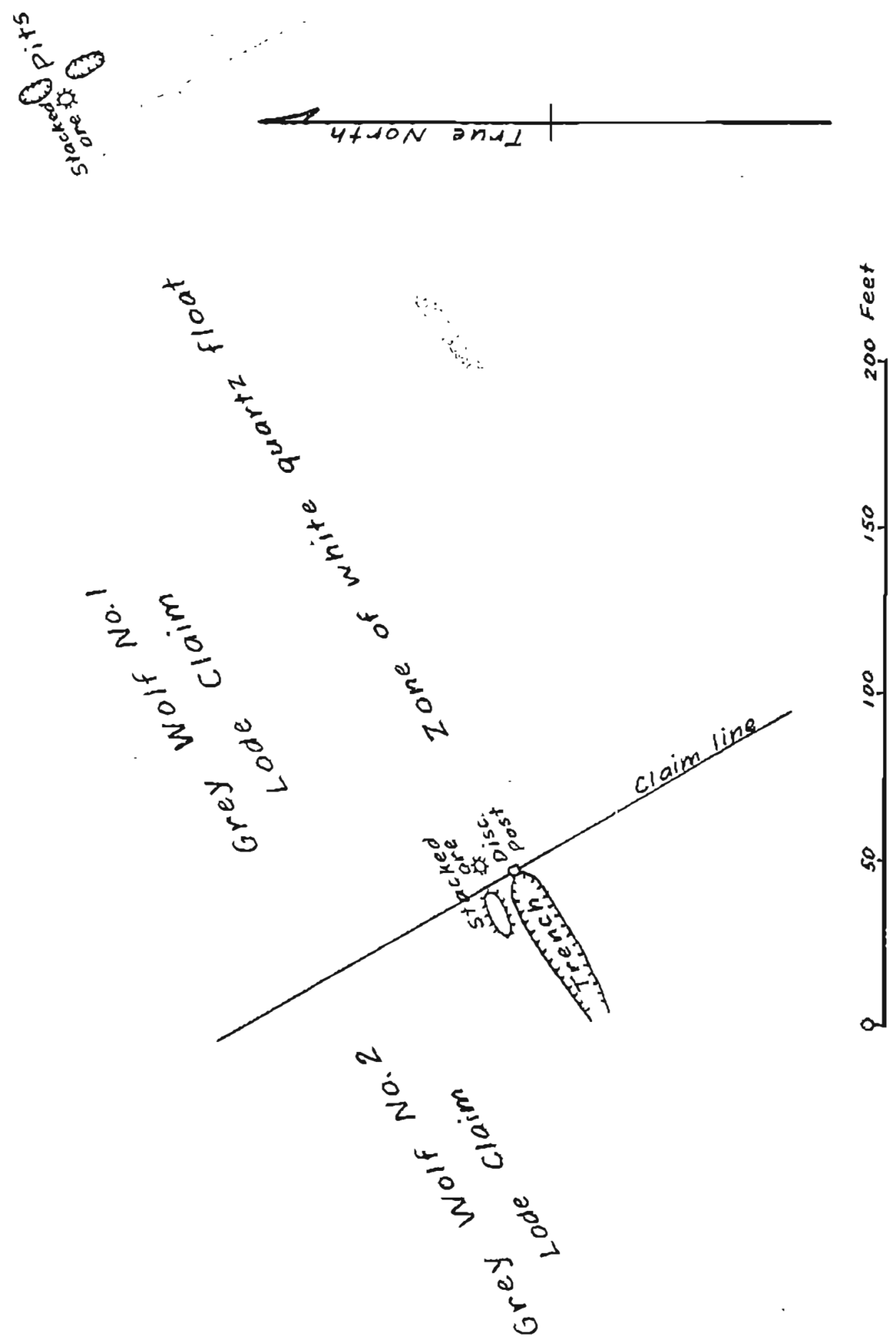

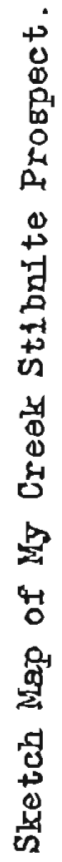


A slight depression, swamp for the most part, was noted orer the quartz zone. Its significance is not undergtood.

Development of the prospect consists of a trench 50 feet long and from three to six feet deep, and several p1ts about four feet deep. Bedrock was apparently reached in the upper end of the trench, which was extended dombill along the rldge in order to carry away seepage water. The trench was partially cared at the time of the examination, so that bodrock was not visible. In the p1ts bedrock coula not be reached bocause of excessive seepage.

No stibnite in place was seen, but a large amount of float has been uncovered In the trench and in the plta for a distance of 275 feet along the quartz zone. About four tons of ore, extimated to contain over 50 percent antimony, as well as geveral tons of lover grade oro, were found in the overburden during prospecting. One piece of high-grade sttbnite meagured 20 inches across and several feet in length. It is likely that considerably spore ore ooourg as float.

Much of the hlgh-grade ore is neerly pure stibntis, containing no other vistole oulfide minerals and practicalig no quartz. In the lower grade ore the only apparent 1mpurity is quartz. The atibnite 1s of the coarse, bladed variety; some of the crystals are an inch wide and six inches long. Although some of it has been altered to jellow oxddes of antimony that are pseudomorphs of stibnite, most of the ore 1s remarkabiy fresh, Wth an exceptionably orilliant lustre. Conclusions

Although no ore in place has been found, the large amount of high-grade float, which eqidently came from an orebody of considerable size, indicates that additional prospecting is worthwile. Since stibntte float is found over a 
distance of 275 feet, it is likely that the ore zone 1 s persistent. Iike most stibnite deposits, howerer, it may pary consideraily in width.

Because of the ret ground and the gentle slopo of the ridge, hand prospecting Is difificut and slow. Surface prospecting could probabig be best done with a bullozorer, supplemented by dynamite to break the larger pieces of quartz. Underground work should not be started until a sultable body of ore has been found by surface prospecting.

\author{
Henry R. Joesting \\ Assoc. Minting ingtueer \\ Eakil Anderson \\ Asal start Mindng Engineer \\ Territorial Department of Mines \\ College, Alaska \\ Oct. 10, 1942 .
}

